\title{
PENGARUH PERHATIAN ORANG TUA TERHADAP PENINGKATAN AKHLAK ANAK
}

\author{
Ata Firmanyah \\ Pascasarjana Institut PTIQ Jakarta \\ Email: pakatakeren137700@gmail.com
}

\begin{abstract}
ABSTRAK
Akhlak merupakan salah satu komponen dasar Islam yang berisi ajaran tentang prilaku atau sopan santun. Atau dengan kata lain akhlak dapat disebut sebagai aspek ajaran Islam yang mengatur prilaku manusia. Dalam pembahasan akhlak diatur mana prilaku yang tergolong baik dan buruk. Akhlak merupakan bagian yang sangat penting dalam ajaran Islam, karena prilaku manusia merupakan objek utama ajaran Islam. Bahkan maksud diturunkannya agama adalah untuk membimbing sikap dan prilaku manusia agar sesuai dengan fitrahnya. Banyak sekali ayat dalam Al-Quran berbicara tentang akhlak atau yang berkaitan dengan akhlak. Ini menunjukkan betapa penting pembinaan akhlak dalam Islam sejak dini, baik di lingkungan keluarga, sekolah maupun masyarakat, agar menjadi manusia yang berbudi pekerti luhur. Namun mendidik anak menjadi memiliki akhlak yang mulia bukanlah persoalan yang mudah apalagi di era perkembangan teknologi yang begitu pesat ini. Banyak sekali faktor yang menghambat dalam peningkatan akhlak anak, diantaranya adalah kurangnya perhatian orang tua terhadap anak, kurangnya keteladanan, pengaruh lingkungan, dan pengaruh perkembangan teknologi yang begitu pesat terutama perkembangan teknologi di bidang telekomunikasi, terutama gawai dan banyak lagi yang lainnya. Banyak sekali masalah-masalah akhlak yang terjadi pada anak-anak. Diantarannya adalah banyak anak-anak yang kurang sopan dan santun, kecanduan video porno, kecanduan bermain games, tawuran, membolos, tidak disiplin, tidak mengerjakan pekerjaan rumah, merokok, kecanduan narkoba, bullying, suka berbohong dan lain sebagainya. Masalah-masalah di atas tentunya di pengaruhi oleh berbagai faktor.
\end{abstract}

Kata kunci: Perhatian Orangtua dan Akhlak Anak. 


\section{Pendahuluan}

Pembahasan terkait akhlak anak selalu menarik untuk di kaji, karena akhlak sangat penting dan merupakan bagian yang tidak dapat dipisahkan dalam kehidupan manusia, terutama dalam keluarga. Pada hakekatnya, para orang tua mempunyai harapan agar anak-anak mereka tumbuh dan berkembang menjadi anak yang baik, mengetahui mana yang baik dan mana yang buruk, serta tidak mudah terjerumus dalam perbuatan-perbuatan yang dapat merugikan dirinya sendiri.

Akhlak merupakan salah satu komponen dasar Islam yang berisi ajaran tentang prilaku atau sopan santun. Atau dengan kata lain akhlak dapat disebut sebagai aspek ajaran Islam yang mengatur prilaku manusia. Dalam pembahasan akhlak diatur mana prilaku yang tergolong baik dan buruk. ${ }^{1}$ Akhlak merupakan bagian yang sangat penting dalam ajaran Islam, karena prilaku manusia merupakan objek utama ajaran Islam. Bahkan maksud diturunkannya agama adalah untuk membimbing sikap dan prilaku manusia agar sesuai dengan fitrahnya. Banyak sekali ayat dalam Al-Quran berbicara tentang akhlak atau yang berkaitan dengan akhlak. Ini menunjukkan betapa penting pembinaan akhlak dalam Islam.

Pembinaan akhlak sangat penting ditanamkan sejak dini agar akhlak anak meningkat lebih baik, baik di lingkungan keluarga, sekolah maupun masyarakat, agar menjadi manusia yang berbudi pekerti luhur. Namun mendidik anak menjadi anak yang sholeh dan sholehah serta memiliki akhlak yang mulia bukanlah persoalan yang mudah apalagi di era perkembangan teknologi yang begitu pesat ini. Banyak sekali faktor yang menghambat dalam peningkatan akhlak anak, diantaranya adalah kurangnya perhatian orang tua terhadap anak, kurangnya keteladanan, pengaruh lingkungan, dan pengaruh perkembangan teknologi yang begitu pesat terutama perkembangan teknologi di bidang telekomunikasi, terutama gawai dan banyak lagi yang lainnya

Banyak sekali masalah-masalah akhlak yang terjadi pada anak-anak. Diantarannya adalah banyak anak-anak yang tidak memiliki sopan santun kepada yang lebih tua, malas belajar, kecanduan video porno, kecanduan bermain games, tawuran, membolos, tidak disiplin, tidak mengerjakan pekerjaan rumah, merokok, kecanduan narkoba, bullying, suka berbohong dan lain sebagainya. Masalahmasalah di atas tentunya di pengaruhi oleh berbagai faktor. Di antara faktor-faktor itu, di duga dipengaruhi oleh kurangnya perhatian orang tua terhadap anak.

Berdasarkan permasalahan yang dikemukakan di atas, agar para orang tua dan pendidik dapat memahami pentingnya akhlak, sehingga orang tua dan pendidik dapat memahami betapa besarnya pengaruh perhatian orang tua terhadap peningkatan akhlak anak-anak mereka, maka penulis bermaksud melakukan penelitian dalam jurnal ini, pada pembahasan tentang "Pengaruh Perhatian Orang Tua Terhadap Peningkatan Akhlak Anak”.

\section{Pembahasan}

\section{Akhlak Anak}

Menurut Abu Ahmadi, akhlak berarti perangai, adat, tabi'at atau sistem perilaku yang di buat. $^{2}$ Menurut Ibnu Maskawih (w.421 H/1030 M) secara singkat mengatakan bahwa akhlak adalah sifat yang tertanam dalam jiwa yang

\footnotetext{
${ }^{1}$ Asmaran, Pengantar Studi Pendidikan, Jakarta: Ilmu Grafindo Persada, 1994, hal. 2.

${ }^{2}$ Abu Ahmadi, Dasar-dasar Pendidikan Agama Islam, Jakarta: Bumi Aksara, 1991, hal.
} 198. 
mendorong seseorang untuk melakukan perbuatan tanpa memerlukan pemikiran dan pertimbangan. ${ }^{3}$

Sementara itu Imam al-Ghazali (1059-1111 M) mendefinisikan dengan agak lebih luas dari Ibnu Miskawih, mengatakan akhlak adalah sifat yang tertanam dalam jiwa, menimbulkan macam-macam perbuatan dengan gampang dan mudah tanpa memerlukan pemikiran dan pertimbangan. ${ }^{4}$ Adapun menurut Soegarda Poerbakawatja dalam Ensiklopedi Pendidikan yang dikutip oleh Asmaran As, dikatakan bahwa: Akhlak ialah "budi pekerti, watak, kesusilaan (kesadaran etik dan moral yaitu kelakuan baik yang merupakan akibat dari sikap jiwa yang benar terhadap kholiqnya dan terhadap sesama manusia". Selanjutnya di dalam Kitab Dairatul Ma'arif, secara singkat akhlak diartikan, sifat-sifat manusia yang terdidik ${ }^{6}$.

Keseluruhan definisi akhlak tersebut di atas tampak tidak ada yang bertentangan, melainkan memiliki kemiripan antara satu dan lainya. Definisidefinisi akhlak tersebut secara substantial tampak saling melengkapi, dan darinya kita dapat melihat lima ciri yang terdapat dalam perbuatan akhlak, yaitu?

1) Perbuatan akhlak adalah perbuatan yang telah tertanam kuat dalam jiwa seseorang, sehingga telah menjadi kepribadiannya.

2) Perbuatan akhlak adalah perbuatan yang dilakukan dengan mudah dan tanpa pemikiran.

3) Bahwa perbuatan akhlak adalah perbuatan dari dalam diri orang yang mengerjakannya, tanpa ada paksaan atau tekanan dari luar. Dalam hubungan ini Ahmad Amin mengatakan, bahwa ilmu akhlak adalah ilmu yang membahas tentang perbuatan manusia yang dapat dinilai baik atau buruk.

4) Bahwa perbuatan akhlak adalah perbuatan yang dilakukan dengan sesungguhnya, bukan main-main atau karena bersandiwara.

5) Sejalan dengan ciri yang keempat, perbuatan akhlak (khususnya akhlak yang baik) adalah perbuatan yang dilakukan karena ikhlas semata-mata karena Allah.

Dari definisi di atas dapat dipahami bahwa akhlak adalah suatu sifat yang tertanam dalam jiwa seseorang dan mendorongnya untuk melakukan sesuatu sesuai dengan kehendak akhlak serta menimbulkan macam-macam perbuatan dengan gampang dan mudah tanpa memerlukan pemikiran dan pertimbangan.

Sementara definisi anak menurut Wasty anak adalah seseorang yang berada pada suatu masa perkembangan tertentu dan memiliki potensi untuk menjadi dewasa. Anak bukan manusia dalam bentuk kecil, atau seorang dewasa minus beberapa hal yang belum dimiliki. ${ }^{8}$ Anak juga dapat diartikan sebagai manusia yang masih kecil atau belum dewasa. ${ }^{9}$

Adapun"Anak"yang dimaksudkan disini adalah anak yang masih dalam tanggungan orang tua, masih memerlukan bimbingan, pembinaan akhlak dari semua pihak, terutama orang tua, guru dan lingkungan masyarakat.

\footnotetext{
${ }^{3}$ Ibnu Miskawaih, Tanzib al-Akhlaq wa Tathhir al-A'laq, Mesir: al-Mathba'ah alMishriyah, 1934, cet. 1, hal. 40.

${ }^{4}$ Imam Abu Hamid Al-Ghazali, Ihya 'Ulumuddin, Juz III, Kairo: Al-Sya'ab, t.t., hal. 56.

${ }^{5}$ Asmaran As, Pengantar Studi Pendidikan, Jakarta: Raja Grafindo Persada, 1994 , Cet. Ke-2. hal. 2

${ }^{6}$ Abdul,. Al -Hamid Yunus, Dairat Ma'arif, Mesir: Al-Syaib, 1987, Jilid 2, hal . 436

${ }^{7}$ Abudin Nata, Akhlak Tasawuf, Jakarta: PT. Gravindo Persada, 2010 Cet ke-9, hal. 4

${ }^{8}$ Wasty, Soemanto, Psikologi Pendidikan, Jakarta: Renika Cipta, 200, Cet ke-IV, hal 176

${ }^{9}$ Daryanto SS, Kamus Besar Bahasa Indonesia, Surabaya: Apollo, 2006, Cet Ke-1,

hal. 38
} 


\section{a. Perbedaan dan persamaan akhlak, moral dan etika}

Di atas telah di jelaskan tentang definisi mengenai akhlak. Sementara moral dari segi bahasa berasal dari bahasa latin, mores yaitu jamak dari kata mos yang berarti adat kebiasaan. ${ }^{10} \mathrm{Di}$ dalam kamus Besar bahasa Indonesia dikatakan bahwa moral adalah penentuan baik buruk terhadap perbuatan dan kelakuan. ${ }^{11}$

Sedangkan secara terminologi menurut W.J.S. Poerdarminta, kata moral memiliki makna ajaran tentang baik buruknya perbuatan dan kelakuan. ${ }^{12}$

Norma-norma moral adalah tolak ukur yang dipakai masyarakat untuk mengukur kebaikan seseorang. Moral yang sebenarnya disebut moralitas. moralitas sebagai sikap hati orang yang terungkap dalam tindakan lahiriah. Moralitas terjadi apabila orang mengambil sikap yang baik karena ia sadar akan kewajiban dan tanggung jawabnya dan bukan karena ia mencari keuntungan. ${ }^{13}$

Sedangkan etika berasal dari bahasa Yunani, yaitu ethos yang memiliki pengertian adat istiadat (kebiasaan), perasaan batin serta kecenderungan batin untuk melakukan sesuatu. ${ }^{14}$

Teori yang menjadi tolak ukur dari persoalan ini adalah bahwa etika merupakan salah satu bidang kajian dari salah satu cabang filsafat yaitu aksiologi.

Dalam kamus umum bahasa Indonesia, etika diartikan ilmu tentang apa yang baik dan apa yang buruk dan tentang hak dan kewajiban moral (akhlak). Dari pengertian kebahasaan ini terlihat bahwa etika berhubungan dengan upaya menentukan tingkah laku manusia. ${ }^{15}$

Pada wilayah praktis dan dikaitkan dengan nilai guna suatu hal dalam kehidupan, maka ditemukan berbagai pengertian. Frans Magnis Suseno misalnya, menguraikan bahwa etika merupakan filsafat atau pemikiran kritis dan mendasar tentang ajaran-ajaran, norma-norma, nilai-nilai serta kebiasaankebiasaan dan pandangan moral secara kritis. ${ }^{16}$

Etika dalam arti ini dimaknai sebagai cabang ilmu filsafat (pikiran kritis tentang suatu ajaran). Selain itu adalah sebagai sebuah ilmu bukan suatu ajaran. Louis O. Kattsoff, juga menegaskan, bahwa etika suatu ilmu pengetahuan yang menetapkan ukuran-ukuran atau kaidah-kaidah yang mendasari pemberian tanggapan atau penilaian terhadap perbuatan. Ilmu pengetahuan ini lanjut Louis, adalah juga membicarakan apa yang seharusnya dikerjakan dan apa yang seharusnya terjadi, dan yang memungkinkan orang untuk menetapkan apa yang bertentangan dengan yang seharusnya terjadi.

\footnotetext{
${ }^{10}$ Asmaran As,Pengantar Studi Akhlak, Jakarta: Rajawali Pers,1992, cet.I, hal. 8

11 W.J,S.Poerwadarminta,Kamus Besar Bahasa Indonesia, Jakarta: Departemen Pendidikan dan Kebudayaan, 1988, hal. 654

${ }^{12}$ Hamid Darmadi, Dasar Konsep Pendidikan Moral, Bandung: Alfabeta, 2009, hal. 51

13 Asri Budiningsih, Pembelajaran Moral Berpijak Pada Karakteristik Siswa Dan Budayanya, Jakarta: Rineka cipta, 2004, hal. 24

${ }^{14}$ M. Sastrapradja, Kamus Istilah Pendidikan dan Umum, Surabaya: Usaha Nasianal, 1981, hal. 144

${ }^{15}$ W.J,S.Poerwadarminta, Kamus Besar Bahasa Indonesia, Departemen Pendidikan dan Kebudayaan, 1988, hal. 650

16 Fransz Magnis Suseno, Etika Dasar Masalah-Masalah Pokok Filsafat Moral, Jogjakarta: Kanisius, 1993, hal.18
} 
Ilmu pengetahuan seperti disebut dengan etika normatif. ${ }^{17}$ Dapat ditegaskan sebagai ilmu pengetahuan, etika jelas membahas asas-asas akhlak (moral) masyarakat. Ia dapat pula diartikan sebagai ilmu yang membahas apa yang baik dan apa yang buruk. Apa yang hak dan bagaimana manusia melaksanakan kewajiban berdasarkan etis dan nilai yang dianut masyarakat

Moral dan etika sama-sama menentukan hukum atau nilai dari suatu perbuatan yang dilakukan manusia untuk ditentukan baik buruknya. Kedua istilah tersebut sama-sama menghendaki terciptanya keadaan masyarakat yang baik, teratur, aman, damai, dan tentram sehingga sejahtera batiniah dan lahiriahnya. Objek dari moral dan etika yaitu perbuatan manusia, ukurannya yaitu baik dan buruk .

Dengan demikian dari penjelasan di atas antara akhlak, moral dan etika memiliki beberapa persamaan dan perbedaan.

Ada beberapa persamaan antara akhlak, moral dan etika yang dapat dipaparkan sebagai berikut:

1) Akhlak, moral dan etika mengacu kepada ajaran atau gambaran tentang perbuatan, tingkah laku, sifat, dan perangkai yang baik.

2) Akhlak, moral dan etika merupakan prinsip atau aturan hidup manusia untuk menakar martabat dan harakat kemanusiaannya. Sebaliknya semakin rendah kualitas akhlak, etika dan moral seseorang atau sekelompok orang, maka semakin rendah pula kualitas kemanusiaannya.

3) Akhlak, moral dan etika seseorang atau sekelompok orang tidak sematamata merupakan faktor keturunan yang bersifat tetap, stastis, dan konstan, tetapi merupakan potensi positif yang dimiliki setiap orang. Untuk pengembangan dan aktualisasi potensi positif tersebut diperlukan pendidikan, pembiasaan, dan keteladanan, serta dukungan lingkungan.

Selain ada persamaan antara akhlak, moral dan etika sebagaimana diuraikan di atas terdapat pula beberapa segi perbedaan yang menjadi ciri khas masing-masing dari ketiga istilah tersebut. Berikut ini adalah uraian mengenai segi-segi perbedaan yang dimaksud:

Akhlak merupakan istilah yang bersumber dari Al-Qur'an dan alSunnah. Nilai-nilai yang menentukan baik dan buruk, layak atau tidak layak suatu perbuatan, kelakuan, sifat, dan perangai dalam akhlak bersifat universal dan bersumber dari ajaran Allah. Sementara itu, etika merupakan filsafat nilai, pengetahuan tentang nilai-nilai, dan kesusilaan tentang baik dan buruk. Jadi, etika bersumber dari pemikiran yang mendalam dan renungan filosofis, yang pada intinya bersumber dari akal sehat dan hati nurani. Etika bersifat temporer, sangat tergantung kepada aliran filosofis yang menjadi pilihan orang-orang yang menganutnya.

\section{b. Faktor-faktor yang mempengaruhi pembentukan akhlak}

Untuk menjelaskan faktor-faktor yang mempengaruhi pembentukan akhlak pada khususnya dan pendidikan pada umumnya, ada tiga aliran yang sudah amat popular. Pertama, aliran Nativisme, Kedua, aliran Empirisme, dan ketiga aliran Konvergensi.

Menurut Zahara Idris nativisme berasal dari bahasa latin nativus berarti terlahir. Seseorang berkembang berdasarkan pada apa yang dibawanya sejak lahir. ${ }^{18}$ Menurut aliran nativisme bahwa faktor yang paling berpengaruh

17 Louis O. Kattsoff, Pengantar Filsafat Alih Bahasa Oleh Soejono Soemargono, Jogjakarta: Tiara Wacana Yogya, 2003, Cet. ke-8, hal.344

${ }^{18}$ Zahara Idris, Dasar-dasar Pendidikan, Bandung: Angkasa,1992 .hal. 6 
terhadap pembentukan diri seseorang adalah faktor pembawaan dari dalam yang bentuknya dapat berupa kecenderungan, bakat, akal, dan lain-lain. Jika seseorang sudah memiliki pembawaan atau kecenderungan kepada yang baik maka dengan sendirinya seseorang itu menjadi baik.

Selanjutnya aliran emperisme. Aliran ini dimotori oleh seorang filosof berkebangsaan Inggris yang rasionalis bernama John Locke (1632-1704). Teori ini mengatakan bahwa anak yang lahir ke dunia dapat diumpamakan seperti kertas putih yang kosong yang belum ditulisi atau dikenal dengan istilah " Tabularasa" (a blank sheet of paper ). Dengan demikian menurut aliran ini anak-anak yang lahir ke dunia tidak mempunyai bakat dan pembawaan apa-apa sebagai kertas putih yang polos. Oleh karena itu, anakanak dapat di bentuk sesuai dengan keinginan orang dewasa yang memberikan warna pendidikan. ${ }^{19}$ Aliran Empirisme dipandang sebagai aliran yang sangat optimis terhadap pendidikan.

Aliran yang ketiga yaitu aliran konvergensi yang berpendapat pembentukan akhlak dipengaruhi oleh faktor internal, yaitu pembawaan si anak, dan faktor dari luar yaitu pendidikan dan pembinaan yang dibuat secara khusus, atau melalui interaksi dalam lingkungan sosial. Fitrah kecenderungan kearah yang baik yang ada dalam diri manusia dibina secara intensif melalui berbagai metode. ${ }^{20}$

Aliran konvergensi itu tampak sesuai dengan ajaran Islam. Hal ini dapat dipahami dari ayat di bawah ini :

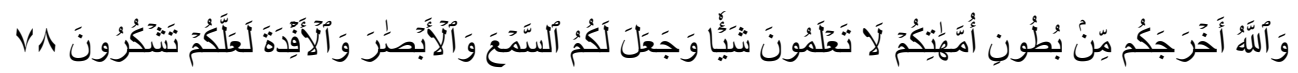

Dan Allah mengeluarkan dari perut ibumu dalam keadaan tidak mengetahui sesuatu apapun, Dan Dia memberi kamu pendengaran, penglihatan dan hati, agar kamu bersyukur. (An-Nahl/16:78).

Menurut tafsir Kementerian Agama RI, maksud dari ayat ini adalah Allah mengeluarkan manusia dari rahim ibunya dalam keadaan tidak mengetahui apa-apa. Tetapi ketika dalam rahim, Allah menganugerahkan potensi, bakat dan kemampuan seperti berpikir, berbahagia dan lain sebagainya. $^{21}$ Ayat tersebut memberikan petunjuk bahwa manusia memiliki potensi untuk dididik, yaitu penglihatan, pendengaran dan hati sanubari.

Dengan demikian faktor yang mempengaruhi pembinaan akhlak anak ada dua, yaitu faktor dari dalam yaitu potensi fisik, intelektual dan hati rohaniyah yang membawa anak dari sejak lahir, dan faktor dari luar yang dalam hal ini adalah kedua orang tua, guru sekolah, lingkungan pergaulan anak, kemajuan teknologi terutama kemajuan teknologi informasi seperti gawai, tokoh-tokoh pemimpin di masyarakat serta pemerintah.

\section{c. Urgensi pembinaan akhlak bagi anak}

Pembinaan akhlak merupakan tumpuan perhatian pertama dalam Islam. Hal ini dapat dilihat dari salah satu misi kerasulan Nabi Muhammad

\footnotetext{
${ }^{19}$ Umar Tirtarahardja, Pengantar Pendidikan, Jakarta: PT Rineka, 2000, hal. 194

${ }^{20}$ H.M.Arifin, Ilmu Pendidikan Islam, Jakarta: Bumi Aksara,1991, Cet. 1, h. 113

${ }^{21}$ Departemen Agama RI, Al-Quran dan Tafsirnya, Jilid V, Jakarta: Lentera Abadi, 2010,
} hal. 359 
SAW yang utama adalah untuk menyempurnakan akhlak yang mulia. ${ }^{22}$ Dalam salah satu hadistnya Rasulullah SAW bersabda :

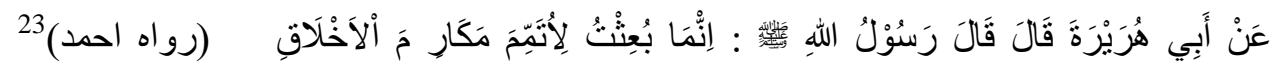

Dari Abu Hurairah r.a berkata: Bersabda Rasulullah SAW." Bahwasanya aku diutus (Allah) untuk menyempurnakan keluhuran budi pekerti (H.R. Ahmad).

Hadist di atas menunjukan betapa pentingnya akhlak, bahkan tujuan Nabi Muhammad diutus kepada umat manusia untuk menyempurnakan akhlak. Oleh karena itu, agama Islam mendorong umatnya untuk memiliki akhlak yang mulia dan akhlak yang luhur. Oleh karena itu, akhlak yang luhur dan mulia termasuk perkara yang ditekankan dalam Islam. Islam menekankan dan mendorong kita untuk memiliki akhlak yang sempurna terhadap Allah swt, Rasulullah saw, dan juga terhadap manusia. Dengan akhlak yang mulia, akan tampaklah kesempurnaan dan ketinggian agama Islam ini, yaitu agama yang indah dan sempurna, baik dari sisi 'aqidah, ibadah, adab dan akhlak.

Begitu banyak ayat Al-Quran yang berbicara tentang akhlak atau yang berhubungan dengan akhlak. Ini menunjukan betapa pentingnya akhlak dalam Islam. Begitu sangat pentingnya akhlak hingga pembinaan akhlak dalam Islam juga terintegrasi dengan pelaksanan rukun iman. Sebagaimana hasil analisis Muhammad al-Ghazali terhadap rukun Islam yang lima telah menunjukan dengan jelas bahwa dalam rukun Islam yang lima terkandung konsep pembinaan akhlak. ${ }^{24}$

Paparan di atas hanya merupakan gambaran umum betapa pentingnya pembinaan akhlak bahkan bagaimana metode yang yang digunakan dalam pembinaan akhlak. Pembinaan akhlak anak dilakukan sejak dini agar kelak mereka bisa menjadi hamba-hamba Allah dan umat Rasulullah yang betulbetul menjadi manusia-manusia yang berakhlak mulia sebagaimana yang Rasulullah contohkan. Dan Rasulullah merupakan contoh terbaik yang pasti jika kita mencontohnya kita akan bersamanya disurga kelak.

Namun mendidik anak agar menjadi anak yang saleh dan berakhlak mulia, bukanlah hal yang mudah. Menurut Psikolog Elly Risman salah satu tantangan terbesar mendidik anak di era modern ini, terutama membina akhlak mereka adalah gawai (gadget $)^{25}$. Beliau mengingatkan bahwa ancaman besar yang sangat berbahaya bagi pengasuhan anak-anak saat ini adalah akan kehadiran gawai. Sayangnya, sebagian besar orang tua di Indonesia masih abai atau tidak begitu memperhatikan terhadap ancaman ini, meski sudah cukup banyak kejadian mengerikan menimpa anak-anak diakibatkan dampak teknologi gadget.

Kemudian selain penggunaan gawai, diduga faktor lain yang menghambat pembinaan akhlak anak adalah faktor lingkungan yang kurang baik. Menurut aliran emperisme lingkungan sangat memberikan pengaruh

${ }^{22}$ Abuddin Nata, Akhlak Tasawuf, Jakarta: Raja Grafindo Persada, 1994, hal. 158

${ }^{23}$ Sayyid Ahmad Hasyimi, Syarah Mukhtarul Ahadist, Bandung: Al-Ma'arif, 1994, hal. 28

${ }^{24}$ Muhammad al-Ghazali, Segarkan Imanmu, Petunjuk Meraih Kemuliaan Moral dan Kebahagian Spiritual, Jakarta: Zaman, 2015, hal. 23

${ }^{25}$ Elly Risman, Seminar Parenting, Mengasuh Anak Platinum di Era Digital, di Auditorium Al-Azhar Cilacap pada hari sabtu 10 Spetember 2016. 
bahkan menjadi faktor yang paling berpengaruh. Aliran ini dimotori oleh seorang filosof berkebangsaan Inggris yang rasionalis bernama John Locke $(1632-1704){ }^{26}$

Kemudian faktor lain yang di duga menjadi hambatan dalam pembinaan akhlak anak adalah kurangnya perhatian dan teladan dari orang tua dan pendidik. Keteladanan merupakan suatu perilaku yang dicontohkan oleh seseorang yang telah memahami terhadap orang yang memahami sesuatu. ${ }^{27}$ Menurut Muhammad Fadhil Al Jamaly, salah satu faktor yang mempunyai pengaruh terhadap pendidikan dan dalam kehidupan manusia sehari-hari adalah, uswatun hasanah atau suri teladan. ${ }^{28}$ Teori keteladanan tidak dapat disangkal telah memiliki peran yang sangat signifikan dalam usaha pencapaian keberhasilan pendidikan, hal itu disebabkan karena secara psikologis, anak didik lebih banyak mencontoh perilaku atau sosok figur yang diidolakannya termasuk orangtua dan gurunya, karena itu orangtua dan seorang pendidik hendaknya menyadari bahwa, perilaku yang baik adalah tolak ukur yang menjadi keberhasilan bagi anak didiknya.

Mendidik anak harus diiringi oleh kekuatan akhlak yang baik dari para orang tua ataupun para pendidik. Sebab jika tidak, maka akan memperlemah atau menimbulkan kekecewaan dan konflik batin dalam diri anak. Perhatian dan tauladan dari orang tua dan pendidik sangat penting dan sangat berpengaruh terhadap pembinaan akhlak anak. Jika orang tua dan pendidik kurang memberikan perhatian dan tidak memberikan teladan yang baik, maka akan sangat sulit menjadikan anak berakhlak mulia. Karena perhatian dan teladan dari orang tua dan pendidik merupakan salah satu kunci keberhasilan pendidikan akhlak. $^{29}$

Dari penjelasan di atas, dapat diduga bahwa beberapa faktor yang dapat menghambat dalam membina akhlak anak adalah efek dari penggunaan gawai dan media elektronik, pengaruh lingkungan yang kurang baik dan kurangnya perhatian dan teladan dari orang tua dan pendidik. Ketika pembinaan akhlak kepada anak tidak maksimal maka akan sangat berpengaruh terhadap peningkatan akhlak anak-anak.

\section{d. Urgensi perhatian orang tua terhadap peningkatan akhlak anak.}

Menurut Kamus Besar Bahasa Indonesia, perhatian berarti hal perbuatan memperhatikan. ${ }^{30}$ Serupa dengan definisi Kamus Besar Bahasa Indonesia di atas, menurut Bimo Walgito, perhatian merupakan pemusatan atau dikonsentrasi dari seluruh aktivitas individu yang ditujukan kepada sesuatu atau sekelompok objek. Makin diperhatikan suatu objek akan makin disadari objek itu dan semakin jelas bagi individu. ${ }^{31}$

\footnotetext{
${ }^{26}$ Umar Tirtarahardja, Pengantar Pendidikan, Jakarta: PT Rineka, 2000, hal. 194

${ }^{27}$ Ratu Aprilia Senja, Kamus Lengkap Bahasa Indonesia, Jakarta: Difa Publiser, 2008, hal. 812 .

${ }^{28}$ Muhammad Fadhil al-Jamaly, al-Falsafah at-Tarbawiyyah Fil Qur'an, diterjemahkan Judi al-Falasani, Konsep Pendidikan Qur'ani, Solo: Ramadhani, Cet. I, 1993, hal. 135.

${ }^{29}$ Abdullah Gymnastiar, Keluarga Kaya Hati, Kiat Efektif Membentuk Keluarga Sakinah, Bandung: Khas MQ, 2005, hal. 37.

${ }^{30}$ Departemen Pendidikan dan Kebudayaan, Kamus Besar Bahasa Indonesia, Jakarta: PT. Gramedia Pustaka Utama, 2008, hal. 245

${ }^{31}$ Bimo Walgito, Pengantar Psikologi Umum, Yogyakarta: Andi Offset, 1981, hal. 56
} 
Sementara Kartini Kartono mengatakan, "perhatian itu merupakan reaksi umum dari organisme dan kesadaran yang menyebabkan bertambahnya aktifitas, daya konsentrasi dan pembatasan kesadaran terhadap satu objek. ${ }^{32}$

Dari beberapa pengertian menurut para ahli di atas, maka penulis dapat mengambil kesimpulan bahwa perhatian adalah pemusatan atau dikonsentrasi dari seluruh aktivitas individu yang ditujukan kepada sesuatu atau sekelompok objek pemusatan atau kesadaran jiwa yang diarahkan kepada sesuatu objek tertentu yang memberikan rangsangan kepada suatu individu, sehingga ia hanya memperdulikan objek yang merangsang itu.

Perhatian orang tua memiliki bentuk yang bermacam-macam. Adapun bentuk-bentuk perhatian orang tua terhadap anaknya, secara garis besar menurut Slameto dapat mencangkup beberapa hal yaitu: memberikan kebutuhan pokok jasmaniah, memberikan bimbingan, nasehat dan kasih sayang, memberikan motivasi dan penghargaan dan memberikan keteladanan. ${ }^{33}$ Sementara menurut Abdullah Nashih Ulwan bentuk-bentuk perhatian orang tua diantaranya memberikan bimbingan keagamaan, memberikan nasehat kepada anak, memberikan pengawasan dan memberian motivasi kepada anak. ${ }^{34}$

Orang tua memberikan peranan yang sangat besar terhadap pembinaan akhlak anak. Islam mengajarkan bahwa orang tua adalah pencetak kepribadian anak pada tahap awal sebelum anak itu dipengaruhi oleh lingkungannya. Baik itu lingkungan bermain maupun sekolahnya. Bagaimana sikap orang tua terhadap anaknya, begitupun kepribadian anaknya. Bahkan orang tua merupakan pemimpin bagi anak di dalam keluarga yang mempunyai tugastugas penting bagi anak-anaknya, termasuk dalam masalah pendidikan terutama pendidikan akhlak. Pendidikan adalah kebutuhan mendasar yang harus di peroleh oleh setiap anak dari orang tuanya, karena pendidikan adalah penentu masa depan anak-anak. Orang tua yang bertanggung jawab adalah orang tua yang selalu memikirkan pendidikan anak-anaknya, bukan sekedar memenuhi kebutuhan sandang dan panganya saja. Bahkan, orang tua hendaknya selalu merasa khawatir seandainya anak-anaknya menjadi generasi yang lemah karena kurangnya pendidikan. Sehubungan dengan hal ini AlQuran surat An-Nisa ayat 9 menjelaskan:

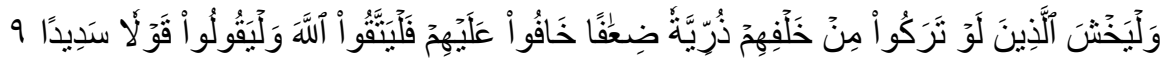

Dan hendaklah takut kepada Allah orang-orang yang seandainya meninggalkan dibelakang mereka anak-anak yang lemah, yang mereka khawatir terhadap (kesejahteraan) mereka. Oleh sebab itu hendaklah mereka bertakwa kepada Allah dan hendaklah mereka mengucapkan perkataan yang benar (QS: an-Nisa/4: 9).

Menurut Tafsir ash-Ashowy, ayat ini turun berkenaan dengan kebiasaan masyarakat pada masa jahiliyah, yaitu apabila ada orang yang hendak meninggal dunia, maka ada beberapa orang yang datang kepadanya supaya dia berwasiat untuk membagi-bagikan hartanya kepada fakir

\footnotetext{
${ }^{32}$ Kartini Kartono, Psikologi Umum, Bandung: Mandar Maju, 1996, hal. 111

${ }^{33}$ Slameto, Belajar Dan Faktor-Faktor Yang Mempengaruhinya, Jakarta: Rineka Cipta. 2003, hal. 60

34 Abdullah Nashih Ulwan, Pendidikan Anak dalam Islam, Kaidah-kaidah Dasar, Bandung: PT Remaja Rosdakarya, 1999, hal. 89.
} 
miskin, sementara dia tidak membagi warisan itu kepada anak-anaknya sehingga anak-anaknya menjadi miskin dan disia-siakan orang. ${ }^{35}$

Dalam tafsir Ibnu Katsir dijelaskan bahwa ayat ini memerintahkan manusia untuk menaati Allah SWT dan memperhatikan ahli warisnya (anak cucunya) sebagaimana dia wajib untuk melaksanakan sesuatu kepada ahli warisnya apabila khawatir mereka itu hidup melarat dan dihina orang lain. ${ }^{36}$ Dari sini jelaslah, bahwa setiap orang tua memang harus mewaspadai agar jangan sampai anak keturunannya hidup sebagai manusia yang lemah, tidak berdaya, terlunta-lunta serta di pandang remeh dan hina. Oleh karena itu, setiap orang tua semestinya melakukan rencana-rencana yang positif guna masa depan anak-anaknya.

Orang tua memiliki kewajiban yang sangat besar terhadap anakanaknya terutama menamankan pembinaan aqidah dah akhlak mereka. Untuk merealisasikan semuanya itu, akan jelas lebih mudah kalau dimulai dari keluarganya sendiri, yaitu dengan cara mendidik dan membina anakanak agar mereka mampu berfikir dan memiliki kepribadian yang Islami yaitu sikap dan tingkah lakunya selalu mencerminkan akhlak yang mulia. Orang tua sebagai pendidik dan pembimbing tidak dapat dipisahkan dengan masa pertumbuhan dan perkembangan anak, tingkah laku dan perbuatan anak. Karena tingkah laku dan perbuatan yang baik tidaklah tertanam dalam diri anak tanpa didasari dengan pendidikan, bimbingan dan pembinaan yang baik dari orang tuanya, lebih-lebih tingkah laku tersebut berkaitan dengan nilai-nilai ajaran agama.

Berdasarkan hal tersebut di atas, berarti besar sekali pengaruh orang tua terhadap pembentukan akhlak anak, dengan demikian tidak dapat diabaikan begitu saja karena baik dan buruknya perbuatan seorang anak akan selalu membawa-bawa nama orang tua. Maka dengan demikian, membimbing, membina mengajarkan dan memberi tauladan yang baik merupakan wujud nyata dari tanggung jawab dan peran orang tua dalam membina akhlak anak.

\section{Kesimpulan}

Penelitian ini dilakukan di MI Miftah Assa'adah yang berlokasi di Jl. Taman Makam Bahagia ABRI RT/RW. 04/04 Kelurahan Parigi, Kecamatan Pondok Aren Tangerang Selatan. Sampel dalam penelitian jurnal ini diambil populasi sebanyak 82 responden dari total 307 populasi di siswa/siswi di Madrasah Ibtidaiyah Miftah Assa'adah. Waktu pelaksanaan penelitian dilakukan pada bulan Juli - Agustus 2019.

Berdasarkan hasil pengujian hipotesis, maka secara keseluruhan temuan dalam penelitian ini, adalah terdapat pengaruh positif dan signifikan perhatian orangtua terhadap peningkatan akhlak anak di MI Miftah Assa'adah. Hal ini dibuktikan dengan hasil nilai probabilitas regresi variabel Perhatian Orangtua $\left(\mathrm{X}_{2}\right)$ dengan variabel Akhlak Anak (Y) sebesar 0,000<0,05. Sedangkan besaran pengaruh yang dihasilkan oleh Perhatian Orangtua berdasarkan beta coefficient adalah 0,575 yang berarti, ketika ada peningkatan satu unit skor Perhatian Orangtua akan berpengaruh terhadap peningkatan skor Akhlak Anak sebesar 0.575 .

\footnotetext{
${ }^{35}$ Ahmad Ashowi al-Maky, Tafsir ash-Ashowy jilid 1, Bairut: Daar Fikr, t.t , hal. 205

${ }^{36}$ Abul Fida Ismail bin Katsir al-Qurasyiyyi ad-Dimasyqi, Tafsir Al-Quran al-Azhim Jilid

1, Bairut: Daar Fikr, 1992, hal. 563
} 


\section{Daftar Pustaka}

Abdullah, Yatim. Studi Akhlaq dalam Perspektif Al-Qur'an, Jakarta: Amzah, 2007.

Ahmadi, Abu dkk. Dasar-dasar Pendidikan Agama Islam, Jakarta: Bumi Aksara, 1991.

Amin, Ahmad. Etika Ilmu dan Akhlaq, Jakarta: Pustaka Panji Mas. 1983.

Arifin, M. Ilmu Pendidikan Islam, Jakarta: Bumi Aksara,1991.

Budiningsih, Asri. Pembelajaran Moral Berpijak Pada Karakteristik Siswa Dan Budayanya, Jakarta: Rineka cipta, 2004.

Darmadi, Hamid. Dasar Konsep Pendidikan Moral, Bandung: Alfabeta, 2009.

Darmawan, Deni. Metode Penelitian Kuantitatif, Bandung: PT. Remaja Rosdakarya, 2013.

Daryanto, SS. Kamus Besar Bahasa Indonesia, Surabaya: Apollo, 2006.

Departemen Agama Republik Indonesia. Metodologi Pendidikan Islam , Jakarta: Direktorat Pembinaan Kelembagaan Agama Islam, 2000.

------, Al-quran dan Tafsirnya. Yogyakarta: PT Dana Bhakti Wakaf, 1995.

Departemen Pendidikan dan Kebudayaan. Kamus Besar Bahasa Indonesia, Jakarta: PT. Gramedia Pustaka Utama, 2008.

Dimasyqi, Abul Fida Ismail bin Katsir al-Qurasyiyyi Tafsir Al-Quran al-Azhim Jilid 1, Bairut: Daar Fikr, 1992.

Direktoral Jenderal Kelembagaan Agama Islam, Wawasan Tugas Guru dan Tenaga Kependidikan, Jakarta: Departemen Agama Islam, 2005

al-Ghazali, Imam Abu Hamid. Ihya 'Ulumuddin, Juz: III, Kairo: Al-Sya'ab, t.t., Hasyimi, Sayyid Ahmad. Syarah Mukhtarul Ahadist, Bandung: Al-Ma'arif, 1994. Idris, Zahara. Dasar-dasar Pendidikan, Bandung: Angkasa,1992.

al-Jamaly, Muhammad Fadhil. al-Falsafah at-Tarbawiyyah Fil Qur'an, diterjemahkan Judi al-Falasani, Konsep Pendidikan Qur'ani, Solo: Ramadhani, Cet. I, 1993.

Kartono, Kartini. Peranan Keluarga Memandu Anak, Sari Psikologi Terapan, Jakarta: Rajawali Press, 1982.

Kattsoff, O Lousi. Pengantar Filsafat Alih Bahasa Oleh Soejono Soemargono, Jogjakarta: Tiara Wacana Yogya, 2003.

Kementerian Agama RI, Al-Quran dan Tafsirnya (Edisi yang di sempurnakan), Jakarta: Lentera Abadi, 2010.

Kusumowardhani, Rani. Pembentukan Karakter Anak, Cilacap: Pendapa Persada, 2017.

al-Maky, Ahmad Ashowi. Tafsir ash-Ashowy jilid 1, Bairut: Daar Fikr, t.t.

Mardapi, Djemari. Faktorn-faktor yang Menentukan Prestasi Belajar Anak FPTK IKIP Yogyakarta, Jakarta: Tesis, pada Fakultas Pascasarjana IKIP, 1984.

Miskawih, Ibnu. Tahfidz al-Akhlaq wa Tathhir al-A'laq, Mesir: al-Mathba'ah alMishriyah, 1934.

Nata, Abuddin. Akhlak Tasawuf, Jakarta: Raja Grafindo Persada, 1994.

Nazir, Mohammad. Bijak dalam Menggunakan Gawai Bagi Anak, Surabaya: Media Pustaka, 2003.

Poerdarminta, W.J.S. Kamus Umum Bahasa Indonesia, Jakarta: Balai Pustaka 1997.

Qardhawi, Yusuf. Peran Nilai dan Moral dalam Perekonomian Islam. Jakarta:Robbani Press, 1995.

Risman, Elly. Parenting++, Jakarta: The Risman Publising, 2016. 
Saebani, Beni Ahmad. Ilmu Pendidikan Islam, Bandung: Pustaka Setia, 2009.

Sastrapradja, M. Kamus Istilah Pendidikan dan Umum, Surabaya: Usaha Nasianal, 1981.

Sayid Ahmad, Hasyim. Syarah Mukhatarul Ahadist, Bandung: Al-Ma'arif, 1994.

Slameto, Belajar Dan Faktor-Faktor Yang Mempengaruhinya, Jakarta: Rineka Cipta. 2003, hal. 60

Suseno, Fransz Magnis. Etika Dasar Masalah-Masalah Pokok Filsafat Moral, Jogjakarta: Kanisius, 1993.

Suwarsi. Pengaruh Gawai Terhadap Perkembangan Anak, Jakarta: Gramedia Pustaka, 2016.

Syah, Muhibbin. Psikologi Belajar, Jakarta: PT. Raja Grafindo Persada, 2003.

Ulwan, Abdullah Nashih. Tarbiatul Aulad Fil Islam,terjemahan, Jakarta: Pustakan Cipta, 1999.

Undang-Undang Tentang Sistem Pendidikan Nasional (UU RI No. 20 tahun 2003) dan Peraturan Pelaksanaannya, Bandung: Citra Umbara, 2010.

Walgito, Bimo. Pengantar Psikologi Umum, Yogyakarta: Andi Offset, 1981.

Wasty, Soemanto. Psikologi Pendidikan, Jakarta: Renika Cipta, 2003. 